\title{
Sharing the country
}

\author{
Peter Read
}

\section{Belonging}

Belonging to the land, to most Indigenous Australians, is one area of Aboriginal identity which seems fairly straightforward. Not so to the growing number of non-Aboriginal Australians who worry that the moral basis of their sense of belonging is not secure. Nugget Coombs believed that not until a legal agreement was drawn up would the status of the non-Indigenous be illegitimate. ${ }^{1}$ Judith Wright felt that the moral gulf between owners and occupiers can never be crossed. ${ }^{2}$ Duncan Graham, who edited the book Being Whitefeller, reflected that the non-Indigenous find shelter and comfort on the proceeds of thieves and killers. Would the buried questions, he asks, like subterranean salt, seep to the surface and poison the future ${ }^{3}$ Manning Clark neatly reversed the concept of assimilation when he wrote

Sometimes when I stand in the Australian bush on a clear windless day I am visited with strange thoughts...I wonder whether I belong. I am ready, and so are others, to understand the Aboriginal view that no human being can ever know heart's ease in a foreign land, because in a foreign land there live foreign ancestral spirits. We white people are condemned to live in a country where we have no ancestral spirits. The conqueror has become the eternal outsider, the eternal alien. We must either become assimilated or live the empty life of a people exiled from their spiritual strength. ${ }^{4}$

Can, will, or should the non-Indigenous belong to Australia as the indigenous do? And if so, how? For several years now I have tried to think through some of the many complexities of post-colonial belonging, though each new article seems to reach a conclusion different from the one before. ${ }^{5}$ I would like these articles to be read, like this one, as my thinking aloud on a problem which seems ever apt to haunt all those who have their emotional roots in one or other of the former colonies of Europe.

To be sure, there are no ultimate answers about belonging; but there are several positions to be asserted, negotiated or traded by every generation, and within each generation, by many Australians of differing experience and ethnicity. Many non-Aborigi-

1. H. C. Coombs, interviewed by the author and reproduced in Read 1994b, p. 378.

2. For example, 'Bond With The Land'in Wright 1991, pp. 13-14

3. 'No Questions Please, We're Australians', in Graham 1994, p. 107.

4. Clark 1997, p. 14.

5. For example, Read 1995 and Read 1994a. 
nal farmers feel that the Australian soil has become part of their blood. First generation migrants have different feelings of belonging to their Australian-born children; suburban householders often feel that they belong to the land differently to pastoralists, or boat-people. Nor, of course, do the Indigenous people occupy any single position. There are marked generational, as well as geographical, differences among Aborigines about whether non-Aboriginal Australians belong to or merely occupy the country. Australians of every variety need to talk to each other, and probably in ways which make us listen afresh. At an Australian Studies Conference about belonging in Copenhagen, 1995, I extracted parts of a dozen discussions which I had recorded with anthropologists and historians about how they felt they belonged in relation to the people and the land with whom they had worked-to fashion a make-believe conversation between them all. There were ten actors in the presentation, two of whom were the original speakers, who read their own lines. ${ }^{6}$

The paper below is the script of a reading at the conference Cultural Implications of the Mabo Debate held at Wagga, in 1994. For the presentation I arranged two interviews I had made in 1993-94 as part-debate, part-play, and further to point the strengths of emotional attachments shared, though in very diverse ways, by the protagonists, I asked the Koori and White readers to reverse the roles. Thus the part of 'Malcolm Gray' the pastoralist, including the words in italics, was read by Mr Hewitt Whyman, a conference organiser and Wiradjuri elder, and the part of 'Uncle Edward', the Victorian Koori, was played by Ms Julie Janson, the non-Aboriginal Australian author of Black Mary and Gunjies. ${ }^{7}$ Though the original speakers are aware of the re-arrangement, I concealed the identities of the speakers for the presentation.

Reaction to the performance was mixed. Non-Indigenous members of the audience waited for Aboriginal reaction. The Aboriginal leaders and spoekespeople were cautious, bemused, unimpressed, a little critical. Aboriginals in the audience who were not community leaders or representatives of organisations were more sympathetic; those raised amongst horses, dogs and sheep well understood Malcolm's heartfelt conjunction of land and work. Some questions were directed at the readers rather than the author. Hewitt Whyman ('Malcolm') was asked-'well why did you chop all those trees down?'

\section{Two modes of belonging}

The presentation began by my asking the audience:

Do non-Aborigines love the landscape? If so, do they love it in the same way that Aboriginal people love the country? And if they do, what gives us non-indigenous people the right to love this land which is, in one sense or another, stolen land?

For several years I have been studying these attachments to special places by nonindigenous Australians, especially in relation to country they loved which has since been lost to them, or destroyed. The people I have worked with include those from countries from which they have emigrated or escaped from and which they can't return to, like Yugoslavia or Vietnam, and farmers driven from rural properties after drought

\footnotetext{
6. Published as Read 1997.
}

7. Published as Janson 1996. 
or debt crises. They include townsfolk from villages now under water like Tallangatta or Adaminaby, people who are still mourning the destroyed city of old Darwin, suburban residents evicted to make way for a motorway in the Sydney suburb of Beecroft and people from ordinary private homes which have been burnt, knocked down or just sold. Many of the feelings of attachment, loss, and mourning, for these lost places are immensely strong.

The first speaker in this exchange is a White pastoralist who no longer lives and works on the country he was born on. I'll call him Malcolm Gray, who as well as farming land of Canberra, was also a high country sheepman. First he speaks of his feelings for that country, then how he felt after he was turned off this land that he'd been born in, and which he'd worked for fifty seven years.

The response is an Aboriginal commentary on Malcolm's predicament of losing his land. It was made by a Victorian Koori elder whose own country more or less adjoins the Snowy Mountains high plains to which Malcolm was so attached. For the purposes of the dialogue I've called him Uncle Edward.

Malcolm's country, to borrow (or is to appropriate?) an Aboriginal way of thinking, ran a hundred kilometres from one side to the other, from Michelago to the Murrumbidgee headwaters near Coolamon, north-south from Yiack to Tharwa. In a residence of 56 years Malcolm Gray knew that land 'as well as the average bloke knows his backyard'.

In a world where the sexes lived their lives more separately than today, the old bushmen had the greatest influence on the boy. One was named William. William showed Malcolm his own special places: That's where Hi [I] used to turn the cattle. Once William gave him the last of the tucker because a young feller needed it more than an old feller like him. I could show you the exact spot where he was sitting. I can still hear the rattle on the slab floor when he came on to the verandah of that old hut. You'd always know who it was by the creaking of the slabs. In the high country William taught him how stop the stock damaging the more delicate vegetation, to care for the rock wallabies. Don't ringbark that tree, there's not many of them. Keep your horse on the trot, don't canter or it'll be the signal for your cattle to panic. William told him something he was to remember well later in his lifeYou can never take an old brumby away from where he was reared. He'll never ever do any good.

On Saturdays from the age of nine or ten, Malcolm would travel by horseback up the road from Tharwa to Naas, then he'd return by the back country, visiting each station to pick up the mail. In the manpower shortages during the Second World War he droved and worked the cattle. He spent the summers up in the high country snow leases. He broke in his first horse at 15. The high plains and the mountains, the different seasons and the ever-changing weather, he believed, had entered his soul. Above all for everyone who's lived in that country and loved it, is that feeling of peace.' You feel safe, you feel secure, everything's familiar, you're in control, you know the seasons. You've seen it all before. He reckoned that the mountains made the character of the men and women who lived there, and that they were pretty tough people. There were deep memories of roaring fires in a mountain hut while the wind howled and the rain came down in buckets. Would have he had loved that hut so much, he wondered, would the memory have 
been so vivid, if he had not spent the day working outside, and the previous half hour feeding and tending his horse in the pouring rain?

Perhaps because he spent so much of his life alone, Malcolm was perfectly content in solitude. Horse, dog and man made a team:

Old bushies talk to them all the time. They make great conversation. And there's nothing more beautiful than to sit on your horse on the top of a high mountain and just look, just look about as far as you can see. There's mountains rolling away, gullies and gorges and all the different colours according to the angle of the sun, the time of the year and the temperature.

Ultimately the mountains for Malcolm meant peace and a personal fulfilment.

A bloke's not blabbing in the pub about what he could do, it's just something he experienced himself and you share the joy with yourself. There's some very special spots, very personal special spots, and I guess that everybody who lives in open spaces has some very special places where they feel security. I don't wish to go into a great spiel about faith and all that sort of thing, but there's some very special places where you can feel very near. And that's a great feeling.

The freshness of the eucalypts after a thunderstorm is something that has to be tested by one's senses. It could never be described. But' the feeling of great peace which descends upon one when alone in these mountains brings with it a realisation of our great creator which cannot be experienced anywhere else. I offer my thanks for being privileged in having this great experience.

Malcolm Gray's country was also socialised country. In 1952 he married Ann who ignored the advice, 'that little bloke's no good for anything off his horse'. Ann's family too had been in the district for over a hundred years. For 35 years they raised their four kids and lived at stations at places which are familiar names to CanberransGudgenby, Honeysuckle Creek, and Naas. We always lived within hearing of a running stream, and at Gudgenby you could predict the degree of frost by the sound of the water coming down the gorge.' I could take you to the exact spot. There were special places which burned into his memory and which he never forgot: the exact spot where he buried his best dog, where he mastered a particularly high-spirited horse, the well where he kept trout alive after catching them in the creek.

All their lives Malcolm and Ann knew that the Federal government would sooner or later resume the farming country in the settled valleys and hills which form the southern end of the Australian Capital Territory. But we never dreamed it would come. In 1968 Malcolm read in the Canberra Times that the 29 property owners in the Orroral valley would be given three months to 'treat', that is, to negotiate the removal of themselves, their stock and belongings out of the valley. There would be free agistment of cattle for the first year, leased adjistment in the second, then the government would resume the land. The Orroral valley was designated as low-level bushland recreation with provision for public access for bushwalking orienteering, camping, public appreciation and education'. The ACT Parks and Conservation Service planners believed that grazing was 'inconsistent with current Australian national park philosophy', recommended that the eastern portion of Gudgenby station be kept as open grassland, the western side to be allowed to 'regenerate naturally' and that any farmer who remained would find life pretty hard from now on. ${ }^{8}$ 
For the next two decades after Malcolm and Ann were invited to negotiate with the government about leaving, the multitude of government departments involved in the creation of the national park dithered about policy. Fourteen separate statutes were in force in the park's legislative management. For a time the graziers, almost all of whom had lived there all their lives, were allowed to remain only on a weekly basis. Improvements were pointless. There was no purpose in putting up a water tank, let alone a lucerne crop, if you didn't know whether you would be around to collect the water or the crop. Employees changed frequently both in the field and in head office. Nobody, in Malcolm's recollection, seemed aware of any kind of overall policy.

Grazing, not just on high country, but anywhere, had become unfashionable in the National Parks. There was a noticeable prejudice in certain areas of the government and the green movement, which, probably in answer to previous equally unbalanced assessments, devalued non-Aboriginal material culture. Though there were the remains of at least a dozen homesteads in the Orroral Valley, and much other evidence of European occupation in the area, it seemed that no government official wanted to know anything about them. A 1976 Australian National Parks and Wildlife Service assessed the cultural history of the area thus:

There are no buildings in the area which, in our opinion, justify preservation, except the slab building near Bobeyan. ${ }^{9}$

And now, one by one, the farmers were leaving. A survey carried out by Australian National Parks and Wildlife predicted that it should be possible to arrange alternative accommodation for these residents without undue hardship or great expense' ${ }^{10}$

\section{Leaving the land}

It was the 5th of March 1986. Malcolm's memories are only of pain:

I'll never forget it

Bloody awful.

All the sheep, cattle, horses, the dogs, all our furniture, all our belongings, the whole lotwent.

The last fifteen sheep were loaded into the trailer of the ute:

A friend came out in his horse trailer and we loaded my horse. It was the last animal to leave the place.

Malcolm's new property was a 3500 hectare farm on the south central plains of New South Wales. It was productive country which, in 1994, Malcolm felt that he could respect but not love: I doubt if it'll ever be that real home here, but it will be to Ann. He had not tried to reset his roots into the plains; no, belonging in new country has to come from within. In the first years after the move, he felt totally alienated. One by one he sold his horses: there were no hills to ride on, so what was the point of keeping them?

A year after his arrival, he wrote a poem about the experience.

8. ACT Parks and Conservation Service 1986, p. 47.

9. Margules and Deverson Pty Ltd 1976, p. 15.

10. Ibid., pp. 6,48 . 
I was sitting out there on the front verandah and the wind was blowing across the stubble paddock with these great swirls of dust. It was dry and it was desolate and it was hot. And I thought to meself, 'My God, what have I done?'

\section{The First Summer after Leaving the Mountains}

As I stand out on this open plain

I think of the place from where I came

Where the everlasting daisies grow.

That's where I would like to go.

Where the alpine ash grows straight and tall

And the lyrebird to his mate he calls

And the magpie with his joyous singing

Sets the mountain ranges ringing.

For the mountain air is so pure and clear

That every bird call one can hear

Now the red dust blows about my feet

And my body wilts from this dreadful heat

What I would give once more to roam

In my beloved mountain home.

The absence of the mountains was almost too much to bear. Worst was the feeling of terrible loneliness I suppose, a craving for familiarity. Malcolm's mind wandered ever to the mountains; I may be an oversensitive bloke, but memories come back every day. It might be the Coolamon Plain, up on the Snowy Mountains, it could be Murray Creek in behind Mt Bimberi, Gudgenby, or riding at Bobeyan with old William when I was a little boy. Could be rabbiting over on the Murrumbidgee River.

Few outsiders seemed to Malcolm to appreciate the achievements of the Orroral farmers, nor the depth of his own attachments. An article in the Sydney Morning Herald praising the Namadgi park for bushwalkers stated that the country was empty because the farmers had failed and abandoned their holdings. Malcolm wrote a reply (which the Herald did not publish) in which he argued that he and his fellow farmers had not walked off, but been forced off:

We didn't walk off owing to failure, but because of Government Resumption and in some cases a leaseback with insecure tenure. The farmers loved and respected and worked with the land and the environment....

To say that these people failed is incorrect. Fine merino wool and cattle were produced on a viable basis. Orroral valley operated by the Gregory family and Gudgenby by the Bootes family, with its magnificent Hereford cattle are two classic examples.

As for people walking off; there are still families at Naas Valley that have remained for four generations....

My wife and I moved out because of resumption and insecure land tenure, not because of any failure.

To the criticism that farmers had no place in national parks, Malcolm wrote his own private answer:

I've smelled the sweat of a wild bush horse

Felt the thrill of a reckless dash 
As we've wheeled the mobs to the mountain yards

To the tune of a greenhide lash.

The mountains at first were my cradle

They later became my home

Now the bosses who live in Canberra

Tell me that in them I no longer can roam

I've seen the mists and the fogs in the valleys

I've seen the beautiful sunset hues

As they change with the season, the mountains

To beautiful mauves and blues

The wildflowers that bloom in the mountains

Come forth with each new spring

How they survive through the harshness of winter

Is truly a remarkable thing.

They tell me the hooves of my horses

Or the trample of cloven feet

Will kill all these beautiful flowers

But this idea sure has me beat.

For a hundred years now and better

Stockmen have used these hills

And as I look over the country

I certainly see no ills.

And now as I enter my twilight

I think and look back on the years

I'm forbidden to live in these mountains

And my only response is my tears.

Malcolm conceded that traditional Aboriginal knowledge of his country was greater than his: Whitefellers like himself lived on introduced food like rabbits and trout. I asked him if it was possible to say who loved the country more? He replied that he didn't know how much the Aboriginal people loved it, but, such was his own love for the land that he could not imagine Aborigines loving it any more than he did. Malcolm felt alienated and unhappy away from his country. He didn't survive by technology or labour, but by an intimate knowledge of the land. He followed similar management practices like burning the grasslands for renewed growth. He could recognise a multitude of species and name certain sites of personal or public significance. Living and working in the country endowed him, he believed, with moral responsibilities to protect certain species of plants and animals. He had an intimate affinity with animals, especially horses and dogs. He sprang from the 'chosen people', the old families who believed they knew it, spoke for it and cared for it. He was taught by older men; he felt he had a right of belonging conferred by birth, memory, long residence and his 46 years of work. Land was something to be loved, enjoyed, lived in and thought about, and also it was a duty, a care, a business, and an employment. Experience and memory created attachment, attachment was love, and farmers like Malcolm and Ann loved their particular part of the country to the depth of their beings. 


\section{Uncle Edward's country}

The differences between non-Aboriginal 'love' of country and Aboriginal attachments are great. Among the most important is that to Aboriginal people there is no intellectual barrier between the physical and non-physical. A boulder may be a boulder and a spirit-being simultaneously. In this enormously spiritualised Aboriginal landscape, animals speak their own language, spirits are objects, trees cry out, the earth weeps.

The response was made by Uncle Edward:

He seems to think that the mountain men were the ones who opened up the hills and the mountains. But the way they opened the land was also to destroy it. They've left behind noxious weeds, they've left behind trails that can never ever be replaced by topsoil again because the hard-hooved animals that cross these trails, and the offspring of these animals are still roaming that land now. The erosion that goes along with all that is more desecration than the stockmen will ever understand...

The other part in that invasion of the high country, there was never ever any respect of the indigenous people of those areas and how they managed to use the land for thousands of years, and how the land provided for their needs in food resources. Now they don't seem to understand that a lot of the very special indigenous plants which are very important to Aboriginal people, which are part of their daily diet or are important as medicine plants, are almost non-existent in those areas any more. The same applies to the coastal area, where there's been any farming or development. Maybe compensation should be paid for that destruction, its something that will certainly be looked at under Mabo Native Title.

I can understand his relationship to that land in that time and that area, but he says there was no harm done by what they were doing, but in realistic terms there was a lot of damage. White farmers don't love the land in the same context as the Aboriginal people. Australian European people have lost contact with the land over the last 2 500-3 000 years...There's no comparison.

I can understand non-Aboriginal people who maybe come from a farming background and have a relationship with the land, and they see a similarity to the land they're using with where they came from, and they become very attached and very spiritualised as well, I suppose, to that country, and feel they're protecting and looking after it; but in realistic terms they're destroying it. But world wide there's an awareness of destroying the country, and people are becoming more concerned about it...I respect [that] in this context, yeah I do think they develop a spiritual relationship with the land.

Malcolm says 'I don't know how much Aboriginal people loved the land, but I couldn't love it more'. Well what he's saying is from his own personal experience. What he's done is never understand the Aboriginal loving of the land. He's never given himself time to understand, maybe never been given the chance to meet Aboriginal people to understand their love for the land; but what he's done is to look through his feelings and his life-span over that land, and he says he loves it. Sure, we understand when he says he loves the land, but he loves it because it's his. He looks at it, and he can see boundary paddocks, and he says 'I love this land because it's mine and no-one's going to come and take it, I want to hand it down to me grandchildren and their grandchildren.'

But the land was already handed down and loved by the Aboriginal people before this man came along with his love for the land. He's stolen the land to love it himself. He should have met the owners to understand how they loved it, so he can love it: he wouldn't have cleared the land then. If he loved the land he wouldn't have cleared it. 
Maybe if they'd 've sat down with the Indigenous owners of this country and got an education about the land and the feeling for the land, then maybe this country wouldn't be so barren and empty now.

Maybe it'd be different if he hadn't cleared any land. Yeah, he's coming from a humanbeing basis. He's surviving, the land's accepted him, and he's giving it respect back by living in harmony with it. He's built himself a little hut at the corner of the bush spot, he's watchin the birds and the animals come each morning, yeah, he's just getting a bit of respect back from what he's contributing to the land.

Yeah, he feels for it more deeply and everything that's in the ecology of that area. And maybe he's connecting up with our ancestors, that spiritual side of things that's helping him.

They mightn't realise it, sometimes they might be camping on a particular spot that's a ceremonial ground, and those spirits will always be there. If he's sitting around the fire at night and he happens to hear the wind howling through the trees, he might think it's the wind, but it's actually the spiritual people talking to him.

Malcolm also revisited his birth country and he also was bitter about its rapid degradation. Soon after he and most of the other families left the Orroral Valley, pigs, wild dogs, rabbits and noxious weeds multiplied. Fences fell down, houses lay empty, were demolished or vandalised. Gardens were overrun, pastures overgrown. He took his son James to have a last look at Horse Gully. It won't be the same again.

After all that the Indigenous people of this land have suffered, and are still suffering, it seems almost the last colonial insult to start claiming that the invaders love the land too. But it's clear that they do. We are serving no useful useful purpose in pretending otherwise

Is there hope of reconciliing the two deep attachments? Have we come to the point when those of us involved in studying the relations between Aborigines and non-Aborigines, all of us anthropologists and linguists and historians, and artists and playwrights and poets and teachers-should stop making the non-Indigenous always the bad guy? Somehow we have to factor these powerful non-Aboriginal emotions into the already powerful and emotional Native Title equation-and into the even wider equation of national identity and belonging.

My question is this: do we need to be as pessimistic as Malcolm and Uncle Edward have been, or are there are areas in which all of us Australians can combine? How do they relate to the other issues of the national debate, like dispossession, deaths in custody, identity, stolen children and belonging?

\section{Claims and counter-claims}

The 1994 conference at which this paper was presented was impelled by the 1992 Mabo judgment, which, as Noel Pearson put it, threw the country into the social, political and psychological turmoil and confusion it had to have. ${ }^{11}$ Another consequence of this turmoil was, I think, the increasing articulation by non-Aborigines of attachments to particular pieces of and rather more firm and more self-conscious than anything they had offered in the previous two or three decades. While most such statements were not

11. Pearson 1996, p. 14. 
exactly put in opposition to Aboriginal claims it would be a mistake to suppose that the authors were entirely ingenuous. The Prime Minister's and some Premiers' refusal to countenance the sharing of pastoral lands foreshadowed in the 1996 Wik judgment seemed to make the whole debate about belonging redundant, had it not been for the determination of local groups in many parts of the country to negotiate an accommodation of interests between the Indigenous people and themselves. ${ }^{12}$

Sharing memories of using the land has proved equally thorny, and for some time the national debate stalled at the general and theoretical. 'Uncle Edward' conceded that those who did not harm the land in any way might think themselves to be True Australians, a generous concession to a city sympathiser, but one which would not help Malcolm who genuinely loved-because he made use of-a particular stretch of land. An unnamed speaker on Radio National said:

We Aboriginal people don't believe that we have a monopoly of spirituality. But we believe that we've practised it a little longer. You can only have that if you're connected to the land and you come from the position of belief in what it represents. $^{13}$

Pat Dodson wrote:

I don't think [non-Aboriginals] are excluded but I do think they've got to grow up and be part of the spirituality that's based on the law of the land. You just don't extend that to people unless they've demonstrated their maturity for it. ${ }^{14}$

A turning point toward the particular may have occurred in August 1998. Aboriginal ceremonial leaders drawn from several parts of the country arrived ritually to cleanse the site of the old Canberra Hospital (soon to be the location of the Australian Museum). During the ceremony they invited non-Aboriginal women to join the Indigenous women as they danced through the smoke of the ritual fires. Many of those women had participated at Canberra Hospital in their own rites of birth, sickness and death; and a child had been killed during the demolition. Not only did the invitation to the non-Aboriginal women seem an act of immense generosity, I thought it also significant because all those present were sharing a quite precise expression of belonging to that site. The Non-Aborigines danced because their memories attached them to that place, the Aboriginals danced because it was Aboriginal land.

Peter Read is a Senior Fellow in the Urban and Environmental Program at the Research School of Social Sciences of the Australian National University, Canberra. He currently chairs the Editorial Board of Aboriginal History.

\section{References}

ABC Radio National 1996, 'Pan, Panic and the Australian Bush'. A documentary, broadcast October.

12. For instance, at the Willandra Lakes National Park, where 16 property owners have signed individual agreements with Aboriginal negotiators.

13. Unnamed Aboriginal speaker in ABC Radio National 1996.

14. Bunbury 1996. 
ACT Parks and Conservation Service 1986, 'Management Plan for Namadgi National Park', photocopied typescript. A copy is held in the CRES Library, Australian National University, Canberra.

Bunbury, Bill, producer 1996, 'Unfinished Business', Hindsight, ABC Radio National, broadcast October.

Clark, Manning 1997, Speaking Out Of Turn, Melbourne.

Graham, D. ed. 1994, Being Whitefeller, Fremantle, Western Australia.

Janson, J 1996, Black Mary. Gunjies. Two Plays, Canberra.

Margules and Deverson Pty Ltd 1976, 'Proposed Gudgenby National Park Land Use Study', Australian National Parks and Wildlife Service, Canberra.

Pearson, N. 1996, 'An Australian History for All of Us', Address to the Chancellor's Club Dinner, University of Western Sydney, 20 November. Xerox. A copy is held in the CRES Library, Australian National University, Canberra.

Read, P. 1994a, '1974: just another year' in The Abundant Culture: Meaning and Significance in Everyday Australia, ed. D. Headon, J. Hooton \& D. Horne, St Leonards, NSW, pp. 199-205.

— 1994b, 'Post-Colonialism and the native born', Canadian Journal of Native Studies, vol. 14, no. 2, pp. 377-390.

- 1994c, 'Who'll take me home?' in Columbus's Blindness, ed. S. Pybus, St Lucia, Queensland.

- 1997, 'Eleven o'clock on the last night of the conference', UTS Review, vol. 3, no. 1, pp. 142-159.

Wright, J. 1991, Born Of The Conquerors, Canberra. 